\title{
Further observations on the effects of intraruminal infusions of volatile fatty acids and of lactic acid on the yield and composition of the milk of the cow
}

\author{
By J. A. F. ROOK, C. C. BALCH AND V. W. JOHNSON \\ National Institute for Research in Dairying, Shinfield, Reading
}

(Received 22 fuly 1964-Accepted 26 October 1964)

The characteristically different effects of continuous intraruminal infusions of acetic, propionic or butyric acid on the yield and composition of the milk of the cow were described in an earlier publication (Rook \& Balch, 1961). This paper reports further experiments to determine, with cows, the effects on milk yield and composition of infusions of these acids when given at high levels of addition or given in combination one with another, and whether the responses to additions vary with the diet of the cow. Some observations are also reported on the effects of intraruminal infusions of $\mathrm{n}$ - and iso-valeric acids, given singly and in combination, of lactic acid and of formic acid on milk yield and composition.

\section{EXPERIMENTAL}

Animals and their management. Lactating Friesian cows with large permanent rumen fistulas were used. They were housed in an experimental byre and the management routine was normal.

Experimental design. Details of the treatments are given in Table I. In Expts $\mathrm{x} a$, $x b, 2,4$ and 5 the order of treatments followed a Latin square design: in Expts 2 and 5, the design was balanced with respect to residual effects. In Expt 3, the treatments were given with each of two diets, according to a split-block design. After the change of diet at the end of the first treatment sequence, a I2-day interval was allowed before the introduction of the second sequence. One cow had to be withdrawn from Expt 3 during the last period of the second treatment sequence.

Foods. In Expts 1, 2, 4 and 5, the daily basal diet consisted of hay ( $16 \mathrm{lb} / \mathrm{cow}$ ) and dairy concentrate cubes (Rook \& Balch, I96I) given at a rate of $4 \mathrm{lb} / \mathrm{gal}$ in Expt I and of $4 \mathrm{lb} / \mathrm{gal}$ less $\mathrm{I} \mathrm{lb}$ in Expts 2, 4 and 5, according to the milk yield of the cow at the beginning of an experiment. The daily amount of cubes was decreased by $2 \mathrm{lb} / \mathrm{cow}$ at the end of each experimental period in Expt $\mathrm{I}$, by $\mathrm{I} \mathrm{lb} / \mathrm{cow}$ in Expts 4 and 5 and by $0 \cdot 7, \mathrm{I} \cdot \mathrm{O}$ or $\mathrm{I} \cdot 3 \mathrm{lb} / \mathrm{cow}$, according to the milk yield at the beginning of the experiment, in Expt 2.

In Expt 3, the diets of the cows at the beginning of the experiment were calculated to provide a starch equivalent of $6.0 \mathrm{lb} / \mathrm{r} 000 \mathrm{lb}$ live weight and $2.6 \mathrm{lb} / \mathrm{iolb}$ milk produced. The diets were altered at the end of each 12 -day period to give a reduction in dietary starch equivalent of $0.52 \mathrm{lb} / \mathrm{day}$. The two diets, designed to give different 
fermentations within the rumen, were meadow hay 8 parts, dairy concentrate cubes ro parts, decorticated groundnut cake 4 parts (diet A), and meadow hay ro parts, dairy concentrate cubes I 3 parts, flaked maize 8 parts, decorticated groundnut cake 4 parts (diet B). The molar proportions of acetic, propionic, butyric and valeric acids in the total volatile fatty acids of rumen liquor were determined in all cows at the end of periods when water only was infused. Mean values for diet A were $61.7,18 \cdot 2,16.5$ and 3.6 respectively and for diet $B 5^{6.4}, 23.1,16 \cdot 1$ and 4.4 .

\section{Table I. Details of experimental design}

\begin{tabular}{|c|c|c|c|c|c|c|}
\hline $\begin{array}{c}\text { Expt } \\
\text { no. }\end{array}$ & $\begin{array}{l}\text { No. } \\
\text { of } \\
\text { cows }\end{array}$ & $\begin{array}{l}\text { Period of } \\
\text { experiment } \\
\text { (months of } \\
\text { lactation) }\end{array}$ & $\begin{array}{l}\text { Duration } \\
\text { of each } \\
\text { treatment } \\
\text { (days) }\end{array}$ & & $\begin{array}{c}\text { Treatment } \\
\text { Infusion given daily }\end{array}$ & $\begin{array}{l}\text { Calories } \\
\text { supplied } \\
(\mathrm{kcal} / \mathrm{day})\end{array}$ \\
\hline I $a$ & 3 & 2nd-4th & 24 & $\begin{array}{l}\text { (a) } \\
(b) \\
(c)\end{array}$ & $\begin{array}{l}\text { I } 50 \mathrm{lb} \text { water } \\
\text { I } 600 \mathrm{ml} \text { propionic acid }+ \text { I } 50 \text { lb water } \\
\text { I } 300 \mathrm{ml} \text { butyric acid }+ \text { I50 lb water }\end{array}$ & $\begin{array}{l}- \\
7920 \\
7460\end{array}$ \\
\hline $\mathbf{I} b$ & 3 & 5 th-8th & 24 & $\begin{array}{l}(a) \\
(b) \\
(c)\end{array}$ & $\begin{array}{l}\text { I } 50 \mathrm{lb} \text { water } \\
\text { I } 500 \mathrm{ml} \mathrm{acetic} \mathrm{acid}+\text { I } 50 \mathrm{lb} \text { water } \\
2000 \mathrm{ml} \text { lactic acid }+ \text { I } 50 \mathrm{lb} \text { water }\end{array}$ & $\begin{array}{l}- \\
5500 \\
7500\end{array}$ \\
\hline 2 & 8 & 2nd-8th & 24 & $\begin{array}{l}(a) \\
(b) \\
(c) \\
(d) \\
(e) \\
(f) \\
(g) \\
(h)\end{array}$ & $\begin{array}{l}\text { I } 50 \mathrm{lb} \text { water } \\
900 \mathrm{ml} \text { acetic acid }+\mathrm{I} 50 \mathrm{lb} \text { water } \\
666 \mathrm{ml} \text { propionic acid }+\mathrm{I} 50 \mathrm{lb} \text { water } \\
575 \mathrm{ml} \text { butyric acid }+ \text { I } 50 \mathrm{lb} \text { water } \\
900 \mathrm{ml} \text { acetic acid }+666 \mathrm{ml} \text { propionic } \\
\text { acid }+ \text { I } 50 \mathrm{lb} \text { water } \\
900 \mathrm{ml} \text { acetic acid }+575 \mathrm{ml} \text { butyric } \\
\text { acid }+ \text { I } 50 \mathrm{lb} \text { water } \\
666 \mathrm{ml} \text { propionic acid }+575 \mathrm{ml} \text { butyric } \\
\text { acid }+ \text { I } 50 \text { lb water } \\
900 \mathrm{ml} \text { acetic acid }+666 \mathrm{ml} \text { propionic } \\
\text { acid }+575 \mathrm{ml} \text { butyric acid }+ \text { I } 50 \text { lb water }\end{array}$ & $\begin{array}{l}- \\
3300 \\
3300 \\
3300 \\
6600 \\
6600 \\
6600 \\
9900\end{array}$ \\
\hline 3 & 6 & 2nd-7th & 24 & $\begin{array}{l}(a) \\
(b) \\
(c)\end{array}$ & $\begin{array}{l}\text { I } 50 \mathrm{lb} \text { water } \\
\text { I } 500^{*} \mathrm{ml} \text { acetic acid }+ \text { I } 50 \mathrm{lb} \text { water } \\
\text { I } 200^{*} \mathrm{ml} \text { propionic acid }+ \text { I } 50 \text { lb water }\end{array}$ & $\begin{array}{l}- \\
5500 \\
5940\end{array}$ \\
\hline 4 & 3 & 2 nd -5 th & 28 & $\begin{array}{l}(a) \\
(b) \\
(c)\end{array}$ & $\begin{array}{l}\text { I50 } \mathrm{lb} \text { water } \\
2000 \mathrm{ml} \text { lactic acid }+\mathrm{I} 50 \mathrm{lb} \text { water } \\
250 \mathrm{ml} \text {-valeric acid }+250 \mathrm{ml} \text { isovaleric } \\
\text { acid }+ \text { I } 50 \mathrm{lb} \text { water }\end{array}$ & $\begin{array}{l}- \\
7500 \\
3300\end{array}$ \\
\hline 5 & 4 & 2nd-5th & 24 & $\begin{array}{l}\text { (a) } \\
(b) \\
(c) \\
(d)\end{array}$ & $\begin{array}{l}\text { I } 50 \mathrm{lb} \text { water } \\
400 \mathrm{ml} \text { formic acid }+\mathrm{I} 50 \mathrm{lb} \text { water } \\
500 \mathrm{ml} \mathrm{n} \text {-valeric acid }+ \text { I } 50 \mathrm{lb} \text { water } \\
500 \mathrm{ml} \text { isovaleric acid }+ \text { I } 50 \mathrm{lb} \text { water }\end{array}$ & $\begin{array}{r}540 \\
3300 \\
3300\end{array}$ \\
\hline
\end{tabular}

* The amount of acid added was varied with the intake of starch equivalent. The figures quoted are for a diet providing 10.5 $\mathrm{kg}$ starch equivalent.

Treatments. The acids (see Table I), diluted with $150 \mathrm{lb}$ water, were infused into the rumen by the technique described previously (Rook \& Balch, 196r). The level of addition of acids in Expt I was increased, by daily increments of $200 \mathrm{ml}$, from $400 \mathrm{ml}$ on the Ist day until either an animal refused food or a level of addition of 21 ./day was reached. With acetic acid, cows began to refuse small quantities of hay at levels of addition of about $1800 \mathrm{ml} /$ day and the amount was then reduced to $1500 \mathrm{ml} /$ day for the remainder of the treatment period. High levels of addition of propionic acid and 
butyric acid, of up to 21 ./day, were achieved temporarily but a refusal of food then occurred and the amounts added were reduced to the levels shown in Table $I$.

With some cows in Expt 2, infusion $(h)$ of acetic acid plus propionic acid plus butyric acid caused small refusals of hay and the levels of addition of the acids were reduced.

Sampling and methods of analysis. The procedure for the sampling of milk and its analysis has been described previously (Rook \& Line, I96I; Rook \& Balch, I96I).

Table 2. Expt I. Treatment mean values, with their standard errors, based on results for the last 8 days of each treatment for each cow, for the yield and composition of the milk of three cows receiving intraruminal infusions of water or solutions of large amounts of acetic, propionic, butyric or lactic acid

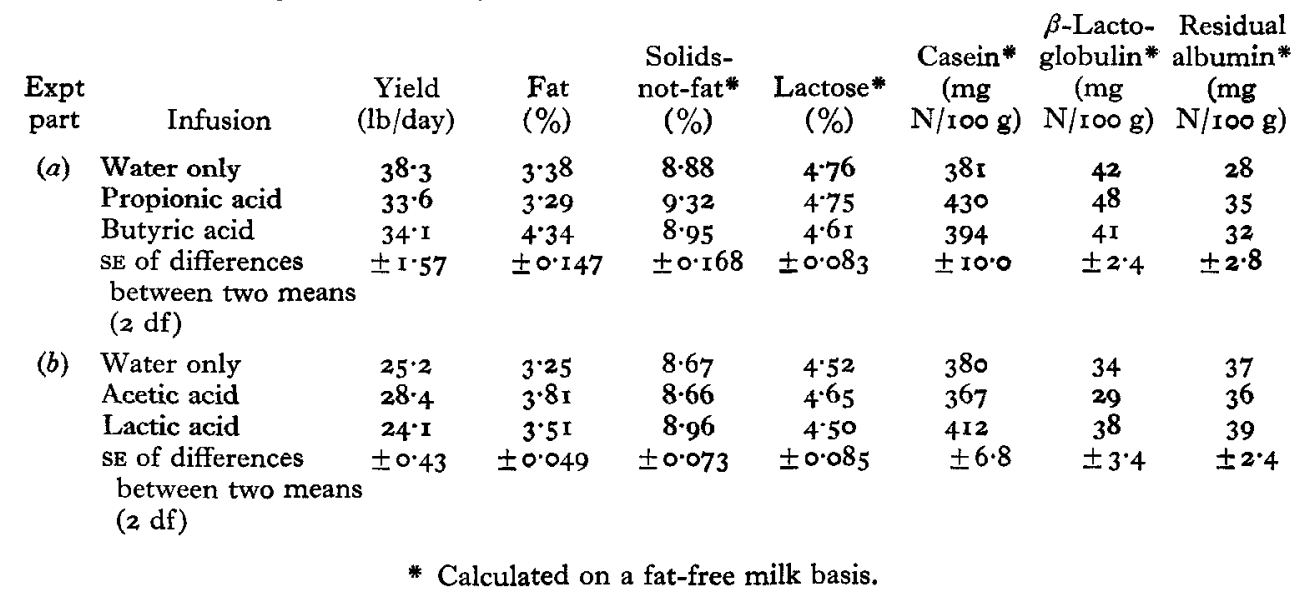

\section{RESULTS}

Effects of the infusion of acids at high levels of addition (Expt $\mathrm{I}$, Table 2). The supplement of acetic acid caused a significant $(P<0.05)$ increase in milk yield, in confirmation of earlier observations, but the high levels of addition of propionic acid and of butyric acid caused a distinct, but not statistically significant $(P>0.05)$, decrease in yield, whereas previously low levels of addition had no effect. This decrease, however, was undoubtedly partly the result of losses in yield associated with the refusal of food at the initial high levels of addition of the acids, losses that were not fully compensated when the levels of addition were reduced and the animals again consumed completely the food offered to them, though a small, specific decrease in milk yield has been noted previously (Storry \& Rook, 1962) with levels of addition of butyric acid above about r $300 \mathrm{ml} / \mathrm{day}$. Lactic acid was without significant $(P>0.05)$ effect on milk yield.

The changes in milk composition were in all instances similar to those reported previously (Rook \& Balch, I96I). Acetic acid and butyric acid increased fat content $(P<0.05)$ but were without significant $(P>0.05)$ effect on solids-not-fat, lactose and protein contents, whereas propionic acid decreased fat content, but not significantly $(P>0.05)$, and increased solids-not-fat and casein contents $(P<0.05)$. Lactic acid increased significantly $(P<0.05)$ fat, solids-not-fat and casein contents. 
Effects of the infusion of acetic, propionic or butyric acids singly or in combination (Expt 2, Table 3). There was no significant $(P>0.05)$ effect on milk yield but the four treatments that included additions of acetic acid gave a yield of milk $\mathrm{I} \cdot 5 \mathrm{lb} /$ day higher on average than the four treatments that did not.

There was a highly significant $(P<0.01)$ effect of treatments on fat percentage. The mean changes were: propionic acid, $-0.2 \mathrm{I}$ percentage units; acetic acid plus propionic acid, -0.05 ; propionic acid plus butyric acid, $+0 . \mathrm{II}$; acetic acid plus propionic acid plus butyric acid, $+0{ }^{\circ} 7$; acetic acid, +0.28 ; butyric acid, $+0.39^{*}$; acetic acid plus butyric acid, $+0.73^{*}$. The differences marked with an asterisk were statistically significant $(P<0.05$, by Duncan's multiple ' $t$ ' test), and in addition the mean value for acetic acid plus butyric acid differed significantly $(P<0.05)$ from the values for acetic acid and butyric acid given separately. These differences in fat content are consistent with a simple additive effect of the various treatments.

Table 3. Expt 2. Treatment mean values, with their standard errors, based on results for the last 8 days of each treatment for each cow, for the yield and composition of the milk of eight cows receiving intraruminal infusions of water, or solutions of acetic, propionic or butyric acids singly or in combination

\begin{tabular}{|c|c|c|c|c|}
\hline Infusion & $\begin{array}{l}\text { Yield } \\
\text { (lb/day) }\end{array}$ & $\begin{array}{l}\text { Fat } \\
(\%)\end{array}$ & $\begin{array}{c}\text { Solids-not-fat* } \\
(\%)\end{array}$ & $\begin{array}{c}\text { Casein }{ }^{*} \\
(\mathrm{mg} \mathrm{N} / 100 \mathrm{~g})\end{array}$ \\
\hline $\begin{array}{l}\text { Water only } \\
\text { Acetic acid }\end{array}$ & $\begin{array}{l}36 \cdot 0 \\
36 \cdot 8\end{array}$ & $\begin{array}{l}3 \cdot 78 \\
4 \cdot 06\end{array}$ & $\begin{array}{l}8 \cdot 87 \\
8 \cdot 83\end{array}$ & $\begin{array}{l}413 \\
406\end{array}$ \\
\hline Propionic acid & $33 \cdot 5$ & 3.57 & $9 \cdot 10$ & 437 \\
\hline Butyric acid & $35 \cdot I$ & $4^{\circ} 17$ & $8 \cdot 91$ & 417 \\
\hline Acetic and propionic acids & $36 \cdot 9$ & 373 & 9.07 & 428 \\
\hline Acetic and butyric acids & $35^{\circ} \circ$ & $4^{-5}-1$ & 9.01 & 424 \\
\hline Propionic and butyric acids & $32 \cdot 3$ & $3 \cdot 89$ & $9 \cdot 16$ & 444 \\
\hline Acetic, propionic and butyric acids & $34^{\cdot} \mathrm{I}$ & $3 \cdot 95$ & $9 \cdot 06$ & 432 \\
\hline SE of differences between two means & $\pm I \cdot 56$ & \pm 0.082 & \pm 0.066 & $\pm 8 \cdot 7$ \\
\hline
\end{tabular}

* Calculated on a fat-free milk basis.

A significant $(P<0.05)$ effect of treatments on solids-not-fat and casein contents was obtained but none of the individual treatment effects was significant $(P>0.05)$. Of the four comparisons available, in each instance the inclusion of propionic acid showed an increase in solids-not-fat and in casein contents, the mean increases being +0.19 percentage units in solids-not-fat content and $+20 \mathrm{mg} / \mathrm{I00} \mathrm{g}$ milk in casein nitrogen content. In contrast, similar comparisons for the infusion of acetic acid and butyric acid showed mean changes in solids-not-fat content of only -0.02 and +0.07 percentage units respectively.

Residual effects were in all instances not significant $(P>0.05)$.

Effects of the infusion of acetic or propionic acids with each of two diets (Expt 3, Table 4). Both diet and infusions were without significant $(P>0.05)$ effect on milk yield, but with diet $A$ the mean value for the infusion of acetic acid was distinctly higher than the means for the infusion of water only or of propionic acid. A similar distinction was not observed with diet $\mathrm{B}$. The mean fat content for $\operatorname{diet} \mathrm{A}$ was significantly $(P<0.05)$ higher, by 0.46 percentage units, than that for diet $\mathrm{B}$. There was also 
a highly significant $(P<0.01)$ effect of infusions on fat content; the characteristic responses for infusions of acetic and of propionic acid were observed with both diets but the increase in fat content in response to the infusion of acetic acid was O.I6 percentage units less with diet $A$ than with diet B. Diet did not have a significant $(P>0.05)$ effect on solids-not-fat and casein contents but the infusion of propionic acid increased the contents of solids-not-fat and casein with both diets and the increases in solids-not-fat content were significant $(P<0.05)$.

Table 4. Expt 3. Treatment and diet mean values, with their standard errors, based on the results for the last 8 days of each treatment for each cow, for the yield and composition of the milk of six cows receiving intraruminal infusions of water or of solutions of acetic or propionic acids with each of two diets

\begin{tabular}{|c|c|c|c|c|c|c|c|c|}
\hline \multirow[b]{2}{*}{ Infusion } & \multicolumn{2}{|c|}{$\begin{array}{c}\text { Yield } \\
\text { (lb/day) }\end{array}$} & \multicolumn{2}{|c|}{$\begin{array}{l}\text { Fat } \\
(\%)\end{array}$} & \multicolumn{2}{|c|}{$\begin{array}{l}\text { Solids-not-fat* } \\
(\%)\end{array}$} & \multicolumn{2}{|c|}{$\begin{array}{c}\text { Casein* } \\
(\mathrm{mg} \mathrm{N} / \mathbf{1 0 0} \mathrm{g})\end{array}$} \\
\hline & Diet A & Diet B & Diet A & Diet B & Diet $\mathbf{A}$ & Diet B & Diet A & Diet B \\
\hline $\begin{array}{l}\text { Water only } \\
\text { Acetic acid } \\
\text { Propionic acid }\end{array}$ & $\begin{array}{l}38 \cdot 9 \\
4 I \cdot 6 \\
38 \cdot 3\end{array}$ & $\begin{array}{l}39 \cdot 2 \\
40 \cdot 0 \\
40 \cdot 2\end{array}$ & $\begin{array}{l}3 \cdot 81 \\
3.91 \\
3.40\end{array}$ & $\begin{array}{l}3 \cdot 28 \\
3 \cdot 54 \\
2 \cdot 93\end{array}$ & $\begin{array}{l}8 \cdot 88 \\
8 \cdot 92 \\
9 \cdot 16\end{array}$ & $\begin{array}{l}8 \cdot 98 \\
8 \cdot 98 \\
9 \cdot 14\end{array}$ & $\begin{array}{l}421 \\
422 \\
438\end{array}$ & $\begin{array}{l}424 \\
416 \\
435\end{array}$ \\
\hline Diet mean values & 39.6 & $39 \cdot 8$ & 3.71 & 3.25 & $8 \cdot 99$ & 9.03 & 427 & 425 \\
\hline $\begin{array}{l}\text { SE of differences between the } \\
\text { means for two infusions with } \\
\text { the same diet ( } 18 \mathrm{df} \text { ) }\end{array}$ & \multicolumn{2}{|c|}{ $\pm I \cdot 10$} & \multicolumn{2}{|c|}{ \pm 0.146} & \multicolumn{2}{|c|}{ \pm 0.062} & \multicolumn{2}{|c|}{$\pm \mathrm{II} \cdot 4$} \\
\hline $\begin{array}{l}\mathrm{SE} \text { of differences between means } \\
\text { for the two diets with the } \\
\text { same infusion ( } 4 \mathrm{df})\end{array}$ & \multicolumn{2}{|c|}{ $\pm 2 \cdot 44$} & \multicolumn{2}{|c|}{ \pm 0.207} & \multicolumn{2}{|c|}{ \pm 0.095} & \multicolumn{2}{|c|}{ \pm 20.5} \\
\hline $\begin{array}{l}\text { SE of differences between means } \\
\text { for the two diets ( } 4 \mathrm{df})\end{array}$ & \multicolumn{2}{|c|}{ $\pm 2 \cdot 27$} & \multicolumn{2}{|c|}{ \pm 0.169} & \multicolumn{2}{|c|}{ $\pm 0.08 I$} & \multicolumn{2}{|c|}{ $\pm 18 \cdot 2$} \\
\hline
\end{tabular}

Table 5. Expt 4. Treatment mean values, with their standard errors, based on results for the last 8 days of each treatment for each cow, for the yield and composition of the milk of three cows receiving intraruminal infusions of water or of solutions of lactic acid or a mixture of $n$ - and iso-valeric acids

\begin{tabular}{lcccc}
\multicolumn{1}{c}{ Infusion } & $\begin{array}{c}\text { Yield } \\
\text { (lb/day) }\end{array}$ & $\begin{array}{c}\text { Fat } \\
(\%)\end{array}$ & $\begin{array}{c}\text { Solids-not-fat* } \\
(\%)\end{array}$ & $\begin{array}{c}\text { Casein* } \\
(\mathrm{mg} \mathrm{N} / \mathrm{I} 00 \mathrm{~g})\end{array}$ \\
Water only & $\mathbf{3}^{8 \cdot \mathrm{I}}$ & $4.0 \mathrm{I}$ & 9.12 & 424 \\
Valeric acid & $\mathbf{3 4 . 5}$ & 4.34 & 9.47 & 467 \\
Lactic acid & 33.4 & 3.78 & 9.37 & $45^{8}$ \\
SE of differences between two means & \pm 2.39 & \pm 0.120 & \pm 0.175 & \pm Ir.5
\end{tabular}
$(2 \mathrm{df})$

* Calculated on a fat-free milk basis.

Effects of the infusion of lactic acid, valeric acid or formic acid (Expts 4 and 5 , Tables 5 and 6). Unusually large errors were attached to the measurements of treatment responses in Expt 4, and though marked differences between the treatment mean values for yield and for fat, solids-not-fat and casein contents were obtained, in no instance was there a statistically significant $(P>0.05)$ difference. As in Expt $\mathrm{I}$, however, the infusion of lactic acid increased solids-not-fat and casein contents, but 
fat content was depressed slightly in contrast to a slight increase in Expt $\mathrm{I}$, and milk yield was markedly depressed. The infusion of a mixture of $\mathrm{n}$ - and iso-valeric acids was associated with a depression in milk yield and increases in fat, solids-not-fat and casein contents. The results of Expt 5, however, suggest that the only real change resulting from the infusion of the isomers of valeric acid is an increase in fat content with the infusion of isovaleric acid, which gave a significant $(P<0.05)$ increase of $0.3^{1}$ percentage units (Table 6). The infusion of formic acid was without effect on milk yield or composition.

Table 6. Expt 5. Treatment mean values, with their standard errors, based on results for the last 8 days of each treatment for each cow, for the yield and composition of the milk of four cows receiving intraruminal infusions of water or of solutions of formic acid, $n$-valeric acid or isovaleric acid

\begin{tabular}{lcccc}
\multicolumn{1}{c}{ Infusion } & $\begin{array}{c}\text { Yield } \\
(\mathrm{lb} / \mathrm{day})\end{array}$ & $\begin{array}{c}\text { Fat } \\
(\%)\end{array}$ & $\begin{array}{c}\text { Solids-not-fat* } \\
(\%)\end{array}$ & $\begin{array}{c}\text { Casein* } \\
(\mathrm{mg} \mathrm{N} / \mathrm{ro0} \mathrm{g})\end{array}$ \\
Water only & 34.2 & $3.7 \mathrm{I}$ & 9.04 & 423 \\
Formic acid & 35.8 & 3.59 & 8.98 & $42 \mathrm{I}$ \\
$n$-Valeric acid & 35.6 & 3.61 & 9.09 & 423 \\
Isovaleric acid & 33.5 & 4.02 & 9.07 & 421 \\
SE of differences between two means & \pm 0.74 & \pm 0.055 & \pm 0.046 & \pm 7.3
\end{tabular}

* Calculated on a fat-free milk basis.

\section{DISCUSSION}

The results now reported for the effects of intraruminal infusions of acetic, propionic or butyric acid on milk yield and composition confirm fully our earlier observations (Rook \& Balch, I96r). In all experiments to date, the infusion of acetic acid has been associated with a mean increase in milk yield, whereas mean responses in yield to the infusion of propionic or butyric acids have been variable. It is worthy of note, however, that in Expt 3 the increase in yield associated with the infusion of acetic acid was less with the diet low in hay and high in concentrates than with the diet containing a more usual proportion of roughage.

Mean decreases in fat content with the infusion of propionic acid and mean increases in fat content with the infusion of acetic acid or butyric acid have also been consistently observed. The magnitude of the responses has varied, however, from experiment to experiment, partly owing no doubt to differences in the amounts of acids added and to differences in the production of volatile fatty acids from the basal diet: marked individual differences in response from cow to cow were observed, however, in these and in other experiments (Storry \& Rook, 1962 and unpublished observations) that cannot be accounted for by either of the above factors.

The infusion of propionic acid has also consistently resulted in an increase in solids-not-fat and casein contents. This response was observed also with the infusion of lactic acid in the experiments described here, and was probably the result of a conversion of lactic acid into propionic acid in the rumen. Increases in the concentrations of both propionic and butyric acids in rumen liquor have been observed (Bath \& Rook, unpublished) after the infusion of lactic acid into cows receiving a diet of hay. 
The relative proportions of propionic and butyric acids produced from lactic acid in the rumen may vary with diet and from animal to animal, and such variation could account for the different responses in fat content to the infusion of lactic acid observed in Expts $I$ and 4.

The cause of the significant increase in fat content observed with the infusion of isovaleric acid in Expt 5 is not clear. Isovaleric acid and also n-valeric acid are known to promote the activity of important cellulolytic bacteria in the rumen (Allison, Bryant \& Doetsch, 1962).

\section{SUMMARY}

I. The effects on the yield and composition of the milk of the cow of intraruminal infusions of dilute aqueous solutions of individual volatile fatty acids, as supplements to basal diets, have been determined in five experiments involving a total of twentyfour cows. In the first experiment infusions of propionic and butyric acids or of acetic and lactic acids were compared, in the second infusions of acetic, propionic and butyric acids singly or in combination, in the third infusions of acetic and propionic acids with each of two diets, in the fourth infusions of lactic acid and a mixture of $\mathrm{n}$ - and iso-valeric acids, and in the fifth experiment infusions of $\mathrm{n}$-valeric, isovaleric and formic acids. In all the experiments an infusion of water only was given as a control treatment.

2. In all instances, infusions of acetic, propionic or butyric acid were associated with characteristic changes in milk yield and composition, as reported previously (Rook \& Balch, 196I). Acetic acid increased milk yield and also fat content, propionic acid depressed fat content but increased solids-not-fat and casein contents, and butyric acid increased fat content. When the infusions of the acids were given in combination, the effects on fat content were additive. No major differences in the responses were observed when the infusions were given with each of two diets, one diet containing a low proportion of hay and a high proportion of concentrated foods and the other a more usual proportion of hay.

3. The infusion of lactic acid was associated with an increase in solids-not-fat and casein contents but varying responses in milk yield and fat content. The infusion of n-valeric acid and isovaleric acid, singly or as a mixture, or formic acid were without significant effect on milk yield and composition with the exception of an increase in fat content associated with the infusion of isovaleric acid.

We thank Dr J. D. Sutton for the determination of the volatile fatty acids in rumen liquor in Expt 3 and Mrs J. J. Gilbey for skilled technical assistance.

\section{REFEREN CES}

Allison, M. J., Bryant, M. P. \& Doetsch, R. N. (1962). F. Bact. 83, 523.

Rook, J. A. F. \& Balch, C. C. (196r). Brit. F. Nutr. 15, 361.

Rook, J. A. F. \& Line, C. (196r). Brit. F. Nutr. 15, 109.

Storry, J. E. \& Rook, J. A. F. (1962). Int. Dairy Congr, xvi. Copenhagen, I, 64. 